on the volatilization of Plativum in ChloRine gag. 479

\title{
On the Volatilization of Platinum in Chlorine Gas.
}

BY F. SEELHEIM.

Berichte der deutschen chemischen Gesel schaft, 12, 2066.

Some years ago I tried the following experiment : a piece of thin platinum foil was placed in a tube of difficultly fusible glass, and heated to bright redness by a gas flame which surrounded the tube. A slow current of chlorine was then conducted through the tube, and continued without interruption for twenty-four hours. At the end of this time.it was found that the tube, behind the foil, was coated with crystals of platinum. The crystals showed the forms $\infty 0 \infty .0, \infty 0, \frac{\infty 0 . \mathrm{n}}{2}$, were beautifully developed, compact, lustrous, and the form could be recognized without the aid of the lense. Subsequently I tried the same experiment in a porcelain tube in a chareoal fire, but continued it for a few bours only. It furnished, again, crystals of the same form, only smaller. I sent a specimen of these crystals, in 1873, to Prof. R. Boettger, in Frankfort. Although the objection cannot be sustained that the platinum was mecbanically transferred by the stream of chlorine, as it, in that case, would necessarily have assumed the form of an amorphous coating, I, nevertheless, recently tried the following experiment, to prove that platinum is volatile in an atmosphere of chlorine:

Some platinous chloride was placed in a small porcelain flask, with a very narrow neck. The flask was coated with loam, and, without closing the opening, heated to light redness in an ordinary portable furnace. After cooling and carefully breaking the flask, it was seen that the platinum had sublimed. A portion formed, in the lower part of the neck, a small sublimate of reticulated crystals, and betow these the sides and bottom of the Hask were coated with microscopic, but completely developed, platinum crystals which showed the lustrous faces above noted. It was evident that a white heat had not been entirely reached, as the platinum vapor would then have ascended to a higher point.

The experiments above communicated prove, with absolute certainty, that platinum is entirely volatile in chlorine gas. No platinous chloride was to be seen in either case. As, therefore, the hypothesis of a dissociation of chlorine in the experiments of $V$. and $C$. Meyer (Berl. Ber., I2, 1426, and this Jouryal, I, 313), rests, as they themselves remark, on the assumption that platinous chloride leaves, when heated, an absolutely non-volatile residue, the fact that, as above 
shown, this assumption is incorrect. deprives the hypothesis of a dissociation of chlorine of the sole foundation on which it rested, and makes it unnecessary for us to have rewourse to the wo hypothetical explanations which Al. Jieben (comptes Rendus, 89, 6. am this JoensaL, I, 4.53) offered on the presumption that the prontain and platinum had erolved no gaseous substande. The late obselved by the Messrs. Meser, that the volume of the chlorine in their experiments was one-third greater than at hwer temperatures, may be explained in perfect hamony with the nborverl facte, by the equation:

$$
\mathrm{Pt}_{2} \mathrm{Cl}_{4}=2 \mathrm{Cl} \mathrm{l}_{2}+\mathrm{H} \cdot \mathrm{Pt}_{2}=-6 \mathrm{rils},
$$

wherein 2 volumes are occupied by platimum vilpur. The experiment gains additional interest from the fict that it represents just as well a determination of the vapor density of platinum as that of chlorine. It only remains to determine by quantitative experiment whether the molecule of platinum consists of one or uf two atoms.

It is another question hew we are te conceive that the platimum volatilizes in chlorine gras. A chemical artion molsi take place, as platinum is not volatile at the same 1 muperature in imbifferent gases. It has already been proven by the experiments of Troost and IIatefeuille (Comptes Rendus, 84,947), that when platimum is lieated to $1400^{\circ} \mathrm{C}$. in chlorine gas, it is deposited in erystak ; anl also, that when the gas is suddenly cooled, platinous chloridr in lepesterd. They assume that the vapor at $1400^{\circ}$ doces not contain platium, hut platinous chloride, which, on eooling, disseciates and leposits platinum in erystals. If this view is correst, then, if the molenle of platinous chloride be $\mathrm{P}_{2} \mathrm{Cl}_{4}$, the vapor density of chlorine in the experiments of the Messis. Meyer would be found to he ereater than the normal figure; whereas, if the molecule be P't l, it would he, at mest, equal to it, and the probability of a dissoniation in the axperingents in guestion would thus be increased. We should, however, rematn hetter in aceord with the direct results of lle experiments and with the phemomena of diswociation, if we should assume that the plitimous chloride in the hot gaseous mixture is not stabli, but in a comblion of eontinual decomposition and recomposition. In this cose there would aluays be present in the gaseous mixture platimus chloride, besides free phatinum, the quantity of which would, at the emperatmes empleyed by $V$. and $($. Meyer, be so small, that it would have no pereeptible effect on the volume. Ilowever that may be, there can be no thought of a dissociation of chlorine until it has been established that the gas experimented on is not contaminated with the vapors of other substances. 